\title{
COMPETITIVENESS IMPLICATIONS FOR IRELAND OF EU ENLARGEMENT
}

\author{
FRANK BARRY \\ AOIFE HANNAN \\ ELAINE HUDSON \\ University College Dublin \\ COLM KEARNEY \\ Trinity College Dublin
}

(Read before the Society, 6 February 2003)

\begin{abstract}
Subject to ratification, a further ten states, primarily from Central and Eastern Europe will accede to the EU in May 2004. Another two, and possibly three, CEE states are likely to join in 2007. The present paper assesses the competitiveness implications of this phase of EU expansion for Ireland. Four specific topics are considered: the opportunities for trade and investment expansion, the implications for Ireland's ability to attract FDI, the likely levels and consequences of immigration from Central and Eastern Europe, and the budgetary implications for the Irish Exchequer.
\end{abstract}

Keywords: Enlargement, trade, investment, migration.

JEL Classification: E47, E62, F17, F22.

\section{INTRODUCTION}

The agreement reached in Copenhagen in December 2002 opens the way for a further ten states - Poland, the Czech Republic, Hungary, Slovakia, Slovenia, Estonia, Lithuania, Latvia, Cyprus and Malta - to join the EU in May 2004. Bulgaria and Romania are likely to be ready to join in 2007 , and there is a possibility that they may be joined by Croatia at that time. The position with regard to Turkey is less clear; if it is judged to fulfil the political conditions for membership by December 2004 then accession negotiations can begin the following year.

Given the small size of the Maltese and Cypriot economies and the continuing uncertainty over the status of the Turkish application, economic analyses have concentrated on the implications of accession by the CEEC10. This is the position adopted in the present paper, which seeks to evaluate the economic implications for Ireland of such an expansion of the EU. 
Previous enlargements saw the accession of Ireland, Denmark and the UK in the 1970s, Greece, Spain and Portugal in the 1980s and Sweden, Finland, and Austria in the 1990s. Enlargement to embrace the CEE10 would raise the land

mass of the EU by 33 percent, the EU population by 105 million (28 percent), and EU GDP (evaluated at purchasing power parity, or PPP) by 11 percent. The population increase compares to the 1973 enlargement of 31 percent. The GDP increase of 11 percent compares to the 1986 enlargement of 12 percent, and the land mass increase compares to each of the previous enlargements.

A major difference in the present case however is the much lower level of development of the current candidate countries. The per capita PPP-based GDP of the current applicants is 39 percent of that of the existing EU-15, compared to an equivalent figure of 61.5 percent for the much smaller accessions (in population terms) of the 1980s. By contrast, the enlargements of the 1970s and 1990s barely affected average incomes.

The economic effects on incumbents of these earlier enlargements pale in comparison to the likely consequences of the accession of the CEEC10, because of this large income difference and because of the size of the agricultural sector in Central and Eastern Europe. Enlargement will double the number of EU farmers and increase the area under agricultural production by one third.

These structural differences have led to hard bargaining over how the Common Agricultural Policy and the Structural Funds programmes will be extended to the new accession countries, with incumbents battling to keep down the budgetary costs of enlargement. While the budgetary implications loom large in the general European policy debate however, the welfare consequences over the longer term are likely to be dominated by the increased trade and factor flows to which enlargement will give rise. Because of the relative sizes of the two groups of economies, the economic effects of enlargement will be much more profound for the CEEC10 than for any of the current incumbents. Amongst incumbents, the strongest aggregatedemand and immigration effects at least are likely to be felt by the Western states that border the CEEC.

Enlargement will nevertheless have important implications for Ireland. It will open up new opportunities for Irish businesses in terms of exporting, outsourcing and outward foreign direct investment (FDI). Ireland's foreign-owned sector will also benefit from the expansion of trade, though the environment in which the country competes for inward FDI will become more competitive. Enlargement will also open up the possibility of labour migration from CEE countries. Most of the current EU15 member states are likely to phase this in over a seven-year transition period, on the assumption that continuing convergence in living standards between the CEEC and the EU15 will reduce the desirability of migration. The Irish authorities appear to have backtracked recently on their decision to allow free labour mobility immediately upon accession. 
The present paper deals with each of these issues in turn. Section one considers the trade effects and assesses the opportunities afforded by enlargement for outsourcing and outward investment. Section two considers the implications for Ireland's foreign-owned sector and for the country's ability to continue to attract technologically advanced foreign industry. Section three analyses the likely pattern of migration flows and its consequences, and Section four assesses the implications of enlargement for the EU budget and the Irish exchequer.

\section{TRADE, OUTSOURCING AND OUTWARD FDI}

Ireland currently trades over 40 times as much with the rest of the EU as it does with the CEEC10, as shown in Table 1. Yet the EU economy is only 20 times larger than the CEEC10 when evaluated in nominal terms, which is the correct measure to be used in this comparison. This summary measure suggests that there are substantial trading opportunities yet to be exploited. ${ }^{1}$

Ireland's main trading partners among the CEEC are Hungary, Poland and the Czech Republic. Trade with each of the other states, and with Malta and Cyprus, is very small by comparison. Ireland runs a trade surplus with most countries other than Hungary, with which it has a large deficit that is driven largely by imports of Office and Data Processing parts and equipment, a perhaps surprising point that will be discussed in further detail later. ${ }^{2}$

Table 1: Irish trade with CEE countries and with the rest of the EU

\begin{tabular}{|l|c|c|c|c|}
\hline & \multicolumn{4}{|c|}{$£$ million } \\
\cline { 2 - 5 } & 1999 Exports & 1999 Imports & 2000 Exports & 2000 Imports \\
\hline Poland & 199 & 69 & 284 & 81 \\
Czech Rep & 154 & 49 & 273 & 86 \\
Hungary & 128 & 192 & 177 & 231 \\
Rest of CEE & 105 & 58 & 200 & 109 \\
Total EU & & & 40296 & 23667 \\
CEE/EU & & & 43 & 47 \\
\hline
\end{tabular}

Source: Central Statistics Office Ireland, Trade Statistics.

The growth in trade is also of interest. Table 2 shows that Irish exports to the CEEC have grown more than 40-fold over the 1990s, while imports have grown even more rapidly. Irish trade relations with the region have expanded much more strongly than have the UK's for example, as the table also illustrates. 
Table 2: Growth in trade with Eastern Europe: Ireland and the UK compared

\begin{tabular}{|c|c|c|c|c|c|c|}
\hline & \multicolumn{2}{|c|}{$\$$ thous } & \multicolumn{2}{|c|}{ \$million } & \multirow{2}{*}{$\begin{array}{c}\text { 1999/1990 } \\
\text { Exports }\end{array}$} & \multirow{2}{*}{$\begin{array}{c}\text { 1999/1990 } \\
\text { Imports }\end{array}$} \\
\hline & $\begin{array}{c}1990 \\
\text { Exports }\end{array}$ & $\begin{array}{l}1990 \\
\text { Imports }\end{array}$ & $\begin{array}{c}1999 \\
\text { Exports }\end{array}$ & $\begin{array}{c}1999 \\
\text { Imports }\end{array}$ & & \\
\hline $\begin{array}{l}\text { Ireland and } \\
\text { Eastern Europe }\end{array}$ & 16242 & 3969 & 728.7 & 445.8 & 45 & 112 \\
\hline $\begin{array}{l}\text { UK and Eastern } \\
\text { Europe }\end{array}$ & 417985 & 160132 & 4495.5 & 3873.6 & 11 & 24 \\
\hline
\end{tabular}

Source: United Nations International Trade Statistics Yearbook, New York.

Note: Eastern Europe comprises a somewhat different set of countries that the CEE10, since there were no separate data for trade with the Baltic States for example in 1990

Trade liberalisation of course has sectoral as well as aggregate implications, the issue to which we now turn. Most bilateral tariffs on manufacturing trade between the EU and CEEC have already been removed under the terms of the Europe Agreements, though impediments to trade in agriculture and food processing remain. Accession will liberalise this dimension of trade and lead to the harmonisation of external tariffs. It will also allow the CEE countries access to the Single European Market.

The customs union dimension, it is generally agreed, will lead to the expansion of the food processing sector in CEE countries at the expense of food processing in the EU15; Francois and Rombout (2001), Lejour et al. (2001). The mechanisms generating this prediction are as follows. Current EU export subsidies are larger than for the CEEC. Removal of export subsidies between the two sets of states will reduce EU15 exports to the CEEC. A reduction in the higher CEE external tariff on agricultural imports will increase the competitiveness of the CEE food processing sector, while the removal of EU tariffs on CEE products is anticipated to increase CEE exports to the EU15. ${ }^{3}$ We deal below with the precise implications these developments might have for the Irish food processing sector.

The second trade effect comes about as a result of CEE accession to the Single Market. Since this entails fiercer competition on firms' home markets while enhancing firms' competitiveness on foreign markets, it will typically be beneficial for sectors that are already export-intensive. All studies to date agreed that CEE sectors such as textiles, clothing and footwear stand to benefit, generally to the detriment of the Southern EU member states. The major sector to expand among the EU15 is predicted to be Machinery and Equipment, in which the EU currently has a strong trade surplus with the CEEC. This sector stands to expand further as a result of increased investment levels in the new EU member states. ${ }^{4}$

Studies disagree on the implications for the motor vehicles and transport sector, with 
some such as Baldwin, Francois and Portes (1997) suggesting that this sector will expand in the EU15 while others such as Lejour et al. (2001) suggest that it will contract. Prediction is made more difficult by the fact that the Transport Equipment sector in the CEEC has been developed in recent years behind high tariff barriers, which will obviously disappear as a consequence of enlargement; Barry (2002). There is evidence however that carmakers are currently moving from Spain to Central Europe. ${ }^{5}$

How will the individual EU incumbent countries fare according to this preliminary analysis? The effects will depend on the importance of these individual sectors in each incumbent country. To surmount transfer-pricing problems we evaluate this in employment terms. The data in Table 3 show the importance of each of these sectors in each country's manufacturing employment relative to the sector's importance in overall EU manufacturing employment.6 Each cell therefore measures, for sector i and country $\mathrm{j},(\mathrm{Lij} / \mathrm{Lj}) /(\mathrm{Li} / \mathrm{LEU})$. We will refer to these as measures of a country's "revealed comparative advantage".7

Table 3: EU15 "Revealed Comparative Advantage" in Particular Sectors

\begin{tabular}{|l|c|c|c|c|}
\hline & $\begin{array}{c}\text { Transport } \\
\text { Equipment } \\
\text { NACE 34,35 }\end{array}$ & $\begin{array}{c}\text { Machinery \& } \\
\text { Equipment } \\
\text { NACE 29 }\end{array}$ & $\begin{array}{c}\text { Food Beverages } \\
\text { and Tobacco } \\
\text { NACE 15,16 }\end{array}$ & $\begin{array}{c}\text { Textiles, Clothing } \\
\text { and Leather } \\
\text { NACE 17-19 }\end{array}$ \\
\hline Belg \& Lux & 0.79 & 0.62 & 1.30 & 0.93 \\
Denmark & 0.50 & 1.54 & 1.63 & 0.41 \\
Germany & 1.24 & 1.35 & 0.72 & 0.42 \\
Greece & 0.70 & 0.38 & 1.90 & 2.31 \\
Spain & 0.81 & 0.60 & 1.43 & 1.29 \\
France & 1.20 & 0.75 & 0.99 & 0.89 \\
Ireland & 0.30 & 0.55 & 1.79 & 0.98 \\
Italy & 0.94 & 1.21 & 0.69 & 1.78 \\
Austria & 0.50 & 1.09 & 0.98 & 0.85 \\
Portugal & 0.40 & 0.38 & 1.05 & 3.60 \\
Finland & 0.44 & 1.25 & 1.00 & 0.48 \\
Sweden & 1.30 & 1.30 & 0.83 & 0.15 \\
United Kingdom & 1.02 & 0.83 & 1.19 & 1.05 \\
Netherlands & 0.58 & 0.98 & 1.48 & 0.41 \\
Total EU 15 & 1.00 & 1.00 & 1.00 & 1.00 \\
\hline
\end{tabular}

Source: Own calculations.

This analysis suggests that Germany will do best as it has a strong comparative advantage in the EU sectors likely to expand and a low presence in the EU sectors which are likely to fare worst. The Cohesion countries, on the other hand - Greece, Spain, Portugal and Ireland - will fare worst according to this analysis because they have a comparative advantage in sectors likely to fare poorly while not having a 
strong presence in the sectors likely to fare best.

Barry and Hannan (2002a) have shown however that it is important to distinguish between foreign and indigenous industry in such comparative advantage analyses. If Ireland has a comparative advantage in some sectors because of the strong presence of foreign industry in the economy, this will serve as an inaccurate predictor of future developments in sectoral structure if the country fails to retain these foreignowned sectors.

Fortunately we do not need to redo the analysis for each EU country, as foreign industry is much less important in other EU countries as it is in Ireland. ${ }^{8}$ Replacing the numbers for total employment in Ireland with those for indigenous industry alone, and redoing the analysis generates the results reported in Table 4.

Table 4: "Revealed comparative advantage": Irish manufacturing and indigenous industry compared

\begin{tabular}{|l|c|c|c|c|}
\hline & $\begin{array}{c}\text { Transport } \\
\text { Equipment } \\
\text { NACE 34,35 }\end{array}$ & $\begin{array}{c}\text { Machinery and } \\
\text { Equipment } \\
\text { NACE 29 }\end{array}$ & $\begin{array}{c}\text { Food Beverages } \\
\text { and Tobacco } \\
\text { NACE 15,16 }\end{array}$ & $\begin{array}{c}\text { Textiles Clothing } \\
\text { and Leather } \\
\text { NACE 17-19 }\end{array}$ \\
\hline $\begin{array}{l}\text { Ireland } \\
\text { (all industry) } \\
\text { Ireland } \\
\text { (indigenous) }\end{array}$ & 0.30 & 0.55 & 1.79 & 0.98 \\
\hline
\end{tabular}

Source: Own calculations from DAISIE database and Irish Census of Industrial Production.

These adjustments show that indigenous industry has a stronger presence than foreign industry in the EU sectors predicted to fare poorly, and has a weaker presence in the heavy capital goods sector, the sector that analyses are agreed is the EU sector that is likely to do best as a consequence of enlargement.

The international analyses from which the above sectoral predictions are drawn do not consider the specific circumstances of the various EU incumbents but instead treat them as a single group. One important point can be made about Ireland's food processing sector however, which is, in employment terms, both the most important indigenous industry and the most important manufacturing sector overall. This sector relies primarily on local agricultural inputs, as evidenced by the fact that it is the sector with the highest share of domestic materials inputs as a proportion of gross output. This tends to be the case internationally also. Irish agricultural produce is different from that in the CEE countries however. The vast bulk of Irish output is of beef and dairy products, with cereals comprising only a small proportion. ${ }^{9}$ In Poland on the other hand, only 20 per cent of agricultural Gross Value Added comes from livestock as opposed to crop production; in Hungary the figure is 25 per cent, in Slovakia 33 per cent and in the Czech Republic 50 per cent. While milk production (along with pork) is important in the Czech Republic in both Hungary 
and Poland pork and poultry are the most important livestock activities; Henrichsmeyer et al. (2000)

It can be surmised therefore that Irish and CEE food processing are not in direct competition. The output of the Central European EU incumbents, on the other hand - countries such as Germany and Austria and to a lesser extent France - is similar to that of the CEE countries. This is confirmed by Ferto and Hubbard (2001, page 6) who show that Irish-Hungarian trade in agri-food products is primarily interindustry, as is Hungary's food trade with Italy, Spain and Greece, while that between Hungary and Austria, the Netherlands, France and Germany is primarily intra-industry. While the Irish sector may suffer alongside other EU incumbents by having export subsidies withdrawn, as a result the growth of the CEE sector will not damage the Irish sector nearly as much as it will certain other EU states. In fact, if accession yields the expected growth benefits to the CEE countries, Irish food processing appears well positioned to gain. ${ }^{10}$

The conventional predictions that EU15 Food Processing and the Textiles, Clothing and Footwear sectors will suffer also ignores the possibility of strategic responses on their part. We now briefly consider these issues - focusing first on outward FDI and then on outsourcing - again with a particular focus on Ireland.

Table 5 shows that the major sectors accounting for overseas acquisitions by indigenous Irish firms are (i) Financial Services, (ii) Construction and Property, (iii) Food and Agribusiness and (iv) Print, Paper and Publishing. While the importance of Irish Financial Services firms in overseas acquisitions reflects international norms, the same cannot be said for the other three sectors. Given the importance of agri-business within Irish indigenous industry, where Food Drink and Tobacco accounts for 27 percent of indigenous manufacturing employment compared to 12 percent of total EU15 manufacturing employment, it is not so surprising that this sector should play a greater role in Ireland's outward FDI than is the case for the rest of the EU. The other two sectors, Construction and Print, Paper and Publishing appear to play a disproportionate role in outward FDI from Ireland however. ${ }^{11}$ 
Table 5: Cross-Border M\&A Activity by sector, average annual share 19931999: (i) by EU firms, (ii) with CEE countries and (iii) by Irish indigenous firms

\begin{tabular}{|l|c|c|c|}
\hline \multirow{2}{*}{} & \multicolumn{3}{|c|}{ Cross-border M\&A activity } \\
\cline { 2 - 4 } & $\begin{array}{c}\text { Purchases by EU } \\
\text { firms worldwide }\end{array}$ & $\begin{array}{c}\text { Sales in Central } \\
\text { and Eastern Europe }\end{array}$ & $\begin{array}{c}\text { Purchases by } \\
\text { Irish firms }\end{array}$ \\
\hline $\begin{array}{l}\text { Food, drink \& } \\
\text { agribusiness } \\
\begin{array}{l}\text { Print, paper \& } \\
\text { publishing }\end{array}\end{array}$ & 5.9 & 17.00 & 17.5 \\
$\begin{array}{l}\text { IT, telecomm. \& } \\
\text { electronics } \dagger\end{array}$ & 2.8 & 0.52 & 16.2 \\
$\begin{array}{l}\text { Chemical and } \\
\text { pharmaceutical. }\end{array}$ & 5.1 & 3.75 & 4 \\
$\begin{array}{l}\text { Other manufacturing } \\
\text { Construction, property }\end{array}$ & 14.4 & 4.58 & 9.5 \\
$\begin{array}{l}\text { Financial services } \\
\text { Services (consulting, }\end{array}$ & 32.3 & 21.25 & 5.8 \\
retail, wholesale etc.) & 14.3 & 0.53 & 22.2 \\
Total & 100 & 25.50 & 22.5 \\
\hline
\end{tabular}

Source: Barry, Gorg and McDowell (2002), from UNCTAD (2000) and CFM Capital Acquisitions Survey (various years)

Note: †This sector comprises Electrical and Electronic Equipment and Precision Instruments

Irish firms have clearly developed valuable proprietary assets in management skills, experience and reputation in these sectors and should be well positioned to develop these assets further in the expanding markets of Central and Eastern Europe. Table 6 indicates that they have already begun to do so. 
Table 6: Acquisitions by Irish indigenous firms in central and Eastern Europe

\begin{tabular}{|c|c|c|c|c|c|}
\hline & Bidder & Target & Country & Sector & Value $\mathbf{6 0 0 0}$ \\
\hline 1993 & Golden Vale & Vonk Pol & Poland & Food and drink & 5969 \\
\hline 1996 & IWP plc & Polbita $(60 \%)$ & Poland & Distribution & 3683 \\
\hline 1997 & AIB & $\begin{array}{l}\text { WBK to } \\
60.1 \%\end{array}$ & Poland & Fin. services & 55118 \\
\hline 1998 & CRH & $\begin{array}{l}\text { Holding } \\
\text { Cement Polski }\end{array}$ & Poland & $C \& P$ & 29210 \\
\hline 1998 & Kingspan & Sunip & Czech & $C \& P$ & 8255 \\
\hline 1998 & AIB & $\begin{array}{l}\text { Chase Fund } \\
\text { Mgt Polska }\end{array}$ & Poland & Fin. services & $\mathrm{N} / \mathrm{D}$ \\
\hline 1999 & AIB & $\begin{array}{l}\text { Bank } \\
\text { Zachodni } \\
\text { (80\% stake) }\end{array}$ & Poland & Fin. services & 563499 \\
\hline 1999 & $\mathrm{CRH}$ & $\begin{array}{l}\text { Cementownia } \\
\text { Rejowiec }\end{array}$ & Poland & $C \& P$ & 28105 \\
\hline 1999 & $\mathrm{CRH}$ & Falbud & Poland & $C \& P$ & N/D \\
\hline 1999 & $\mathrm{CRH}$ & $\begin{array}{l}\text { Mirbud } \\
(72.5 \% \text { stake })\end{array}$ & Poland & $C \& P$ & $\mathrm{~N} / \mathrm{D}$ \\
\hline 1999 & $\begin{array}{l}\text { M'facturers' } \\
\text { services } \\
(\mathrm{MSL})\end{array}$ & $\begin{array}{l}\text { Phillips } \\
\text { (Polish PCB } \\
\text { division) }\end{array}$ & Poland & $\begin{array}{l}\text { IT \& } \\
\text { telecomm. }\end{array}$ & $\mathrm{N} / \mathrm{D}$ \\
\hline 2000 & Barlo Group & PSC & Slovakia & $\begin{array}{l}\text { Print, paper \& } \\
\text { packaging }\end{array}$ & 13589 \\
\hline 2000 & $\mathrm{CRH}$ & Gozdnica & Poland & $C \& P$ & 7239 \\
\hline 2000 & $\mathrm{CRH}$ & $\begin{array}{l}\text { Termo- } \\
\text { Organika }\end{array}$ & Poland & $C \& P$ & N/D \\
\hline 2000 & $\mathrm{CRH}$ & Polbet $(75 \%)$ & Poland & $C \& P$ & $\mathrm{~N} / \mathrm{D}$ \\
\hline 2000 & $\mathrm{CRH}$ & Creg $(51 \%)$ & Poland & $C \& P$ & N/D \\
\hline 2001 & $\mathrm{CRH}$ & PRD Budostal & Poland & $C \& P$ & $\mathrm{~N} / \mathrm{D}$ \\
\hline
\end{tabular}

Source: Chapman Flood Mazars acquisition surveys.

Note: $\quad \mathrm{N} / \mathrm{D}$ denotes value not disclosed;

$\mathrm{C} \& \mathrm{P}$ denotes construction and property. 
Nor is enlargement necessarily detrimental to the EU15 Textiles and Clothing sector, given the possibility of outsourcing to CEE countries. Outsourcing entails splitting up the production process and importing intermediates formerly sourced domestically. This process allows for increased specialisation, generating further gains from trade liberalisation. Austria's proximity to the CEE candidate countries means that outsourcing has advanced particularly rapidly in its case, and it has been found to be particularly important in less skill-intensive sectors including Wood Products and Textiles; Egger et al. (2001). ${ }^{12}$ They find it to have been an important source of total factor productivity growth in these sectors, though overall welfare effects depend on the extent of labour market flexibility in the outsourcing countries since it can otherwise lead to unemployment. Other studies such as Anderton and Brenton (1999) find that outsourcing leads to an increase in both the wage bill share and the employment share of skilled workers in companies located in the countries engaged in outsourcing. It therefore represents a step upwards on the ladder of comparative advantage.

\section{IMPLICATIONS FOR INWARD FDI}

Enlargement will considerably enhance the attractiveness of the CEE countries as a location for export-oriented foreign direct investment, and as such will allow them compete more strongly for such investments. This will arise even though there is already almost complete free trade in manufactures between the EU and the CEEC.

Foreign investors are unlikely to see free trade as equivalent to EU membership for a number of reasons. First is the fact that efforts to remove any remaining non-tariff barriers are likely to be pursued more vigorously in the case of intra-EU trade. Secondly, accession will increase the confidence of foreign investors by allowing for the possibility of appeal beyond the courts of the associated countries to those of the European Union in the event of legal disputes arising. Thirdly, EU membership serves as some guarantee of transparency in the legal and business environment because of the acquis communautaire and the culture of checking the probity of Structural Funds expenditures. Fourthly, entry to the Single Market will fully remove customs frontiers and trade barriers associated with differing technical standards, and will allow full access to government procurement contracts throughout the EU. For all of these reasons, accession is likely to represent as dramatic a change in the CEE climate for foreign investors as it did in the Irish case in 1973; Barry (2002).

Will Ireland compete directly with the CEE countries for foreign investment? There is some possibility that this could arise. A number of them have followed Ireland's lead in offering low rates of corporation tax, and the more advanced ones do not differ substantially from Ireland in terms of the skill levels of the population, while labour costs in CEE countries are very much lower. Furthermore, the productivity level of the workforce is arguably endogenous, reflecting success or failure at attracting FDI, rather than an exogenous factor that determines the likelihood of 
success or failure in this regard. Upon accession, several of the CEE countries will have equally abundant access to the high-income markets of Western Europe, a factor that is of particular importance for some industries according to the analysis of Midelfart-Knarvik et al. (2000). ${ }^{13}$ Subsets of such industries are likely to enjoy equally stable macro policy environments and equivalent regulatory and public administration systems. ${ }^{14}$ This opens up the possibility that they might compete directly with Ireland for the type of FDI that Ireland has been successful in attracting thus far; Barry and Hannan (2001).

In counter distinction however, previous episodes of trade liberalisation in Europe have increased the pool of FDI both from within Europe and from outside; Dunning $(1997 \mathrm{a}, 1997 \mathrm{~b})$. The goods produced by multinational firms also tend to have relatively high income elasticities of demand so that the expected growth in the CEEC10 consequent on enlargement should generate further flows of FDI into and within the newly expanded EU; Barry and Hannan (2002b). A further relevant detail is that the Single Market liberalisation was associated with an expansion in the average number of plants that the leading multinational firms in the EU maintained. Among such firms with plants in Ireland for example, the average number of other EU countries in which they maintained plants rose from 3 in 1987 to 5 in 1993; Pavelin (2000). This suggests that the development of the Single Market was associated with a further fragmentation of the production chain. If this proves to be the case it will be efficiency enhancing and should operate to further benefit Ireland's foreign-owned industry.

What is the evidence on this so far? Some indications can be gleaned from an analysis of Ireland's trade linkages with CEE countries in the sub-sectors of Irish manufacturing that are predominantly foreign-owned. The trade (SITC) sectors that are largely foreign-owned, according to the Irish output and employment data are: Pharmaceuticals (SITC 54), Office and Data Processing Equipment (SITC 75), Telecommunications Equipment (SITC 76), Electrical Machinery, Apparatus and Appliances (SITC 77) and Professional and Optical Instruments (SITC 87/8).

Ireland has a substantial trade surplus as against each of the CEE countries in Pharmaceuticals and Professional and Optical Instruments; Tables $7 \mathrm{a}$ and $7 \mathrm{~b}$. $^{15}$ Office and Data Processing is different. Here Ireland has a strong trade surplus against each of the economies other than Hungary, with which it has a large deficit. The reasons for this are interesting and will be discussed below. A similar though less dramatic situation prevails in Telecommunications. In Electrical Machinery and Equipment Ireland ran a deficit against Poland in 1999 and against the Czech Republic in 2000. 
Table 7a: Ireland's trade with selected CEE countries in Ireland's foreigndominated sectors, 1999

\begin{tabular}{|l|cc|cc|cc|cc|}
\hline \multirow{2}{*}{1999} & \multicolumn{2}{|c|}{ Hungary } & \multicolumn{2}{c|}{ Czech Rep } & \multicolumn{2}{c|}{ Poland } & \multicolumn{2}{c|}{ Estonia } \\
\cline { 2 - 9 } & Irish X & Irish M & Irish X & Irish M & Irish X & Irish M & $\begin{array}{c}\text { Irish } \\
\text { X }\end{array}$ & $\begin{array}{c}\text { Irish } \\
\text { M }\end{array}$ \\
\hline Total trade & $\mathbf{1 6 2 , 5 8 6}$ & $\mathbf{2 4 3 , 7 1 4}$ & $\mathbf{2 0 3 , 1 6 9}$ & $\mathbf{6 2 , 6 6 2}$ & $\mathbf{2 5 4 , 0 2 1}$ & $\mathbf{8 7 , 6 1 2}$ & $\mathbf{9 8 5 1}$ & $\mathbf{6 4 2 7}$ \\
Md / Pharm & 3305 & 1182 & 5769 & 60 & 11,148 & 13 & 174 & 0 \\
ODP & 43,871 & 210,542 & 81,372 & 2858 & 100,234 & 2512 & 5713 & 60 \\
Telecomm & 2214 & 13,088 & 44,140 & 6747 & 12,040 & 6934 & 488 & 23 \\
Elec & 10,926 & 6281 & 3239 & 2618 & 4010 & 6748 & 273 & 1 \\
Prof / Opt & 742 & 224 & 1918 & 107 & 1230 & 132 & 95 & 0 \\
\hline
\end{tabular}

Source: Central Statistics Office Trade Statistics

Notes: $\quad$ 54: Md/Pharm; 75: ODP; 76: Telecomm; 77: Elec; 87/88: Prof/Opt;

$\mathrm{X}$ denotes exports; $\mathrm{M}$ denotes imports;

Figures for 1999, expressed in €(thousands).

Table 7b: Ireland's trade with selected CEE countries in Ireland's foreigndominated sectors, 2000

\begin{tabular}{|l|cc|cc|cc|cc|}
\hline \multirow{2}{*}{2000} & \multicolumn{2}{|c|}{ Hungary } & \multicolumn{2}{c|}{ Czech Rep } & \multicolumn{2}{c|}{ Poland } & \multicolumn{2}{c|}{ Estonia } \\
\cline { 2 - 8 } Total trade & Irish X & Irish M & Irish X & Irish M & Irish X & Irish M & Irish X & Irish M \\
\hline Md / Pharm & $\mathbf{2 2 4 , 3 5 6}$ & $\mathbf{2 2 9 , 6 5 8}$ & $\mathbf{3 4 6 , 5 4 6}$ & $\mathbf{1 0 9 , 8 6 2}$ & $\mathbf{3 6 1 , 0 2 0}$ & $\mathbf{1 0 2 , 6 2 5}$ & $\mathbf{2 5 , 6 6 9}$ & $\mathbf{1 5 , 8 3 1}$ \\
ODP & 5,145 & 1,310 & 12,414 & 118 & 18,973 & 14 & 106 & 1 \\
Telecomm & 49,485 & 240,031 & 100,623 & 5,802 & 130,058 & 1,982 & 6,949 & 76 \\
Elec & 3,229 & 19,952 & 119,621 & 13,768 & 25,090 & 7,455 & 654 & 975 \\
Prof / Opt & 38,985 & 15,022 & 6,678 & 8,006 & 9,965 & 8,525 & 7,525 & 323 \\
& 512 & 389 & 2,499 & 118 & 1,847 & 177 & 31 & 0 \\
\hline
\end{tabular}

Source: Central Statistics Office Trade Statistics

Note: $\quad$ 54: Md/Pharm; 75: ODP; 76: Telecomm; 77: Elec; 87/88: Prof/Opt; $\mathrm{X}$ denotes exports; $\mathrm{M}$ denotes imports.

Figures for 2000, expressed in $€$ (thousands). 
We will concentrate primarily on Irish-Hungarian trade links in Office and Data Processing Equipment (SITC Division 75), as this is Ireland's main export sector, while Hungary has the most advanced foreign-owned and export-oriented ODP sector amongst the CEE countries.

Ireland had an overall trade surplus in the Office and Data Processing sector (SITC Division 75) in the late 1980s and this situation continues to prevail today. Hungary by contrast had a trade deficit from an earlier period, but now runs a surplus with the rest of the world, with a substantial surplus against Ireland. The proposition we want to explore is whether Hungary's growing strength is threatening Ireland's position in the ODP sector.

Looking at Ireland's trade with the rest of the world in Office and Data Processing Machinery, but disaggregated now down to five-digit SITC headings, we see that the important import and export sectors (i.e. comprising exports or imports of over 1 billion euro in any of the years 1999, 2000 or 2001) in recent years are as shown in Table 8, while the equivalent position for 1990 (for sectors trading more than $£ 100$ million at the time) before the Hungarian computer sector began to develop was as illustrated in Table 9.

Table 8: Ireland's external trade in SITC Division 75 (Office and Data Processing Machinery), recent period

\begin{tabular}{|c|c|c|c|}
\hline SITC heading & Exports & & Imports \\
\hline 752.20 & $*$ & $>$ & $*$ \\
752.30 & $*$ & & \\
752.60 & & & $*$ \\
752.70 & $*$ & $=$ & $*$ \\
752.90 & & & $*$ \\
759.97 & $* *$ & $>$ & $* *$ \\
\hline
\end{tabular}

Source: Unpublished CSO Trade Statistics

Legend: * denotes an important sector;

** implies the most important export and/or import sector;

$>$ implies exports greater than imports. 
Table 9: Ireland's external trade in SITC Division 75

(Office and Data Processing Machinery), 1990

\begin{tabular}{|c|c|c|c|}
\hline SITC heading & Exports & & Imports \\
\hline 752.20 & $*$ & & $*$ \\
752.30 & $*$ & $>$ & $*$ \\
752.60 & & & $*$ \\
752.70 & & & \\
752.90 & & & $* *$ \\
759.97 & $* *$ & $>$ & \\
\hline
\end{tabular}

\footnotetext{
Source: Unpublished CSO Trade Statistics

Legend: * denotes an important sector;

** implies the most important export and/or import sector;

$>$ implies exports greater than imports.
}

Thus Ireland has remained a net exporter of segments 752.20, 752.30 and particularly 759.97, while tending to be a net importer of 752.60, 752.70 and 752.90.

Ireland runs an overall trade surplus with the rest of the world in SITC 752 and 759, whilst Hungary runs a surplus with the rest of the world in 752 and a deficit in 759 . It comes as little surprise therefore, that the vast bulk of Irish imports from Hungary are in SITC 752.60 and SITC 752.70, sub-sectors in which Ireland has always tended to run trade deficits with the rest of the world, while the vast bulk of Ireland's exports to Hungary and the other CEE countries are in SITC 759.97, which is Ireland's major export sub-sector in the ODP industry. This suggests that Ireland's trade with Hungary in ODP-related products are in complementary rather than substitute goods; i.e. that Ireland and Hungary form part of the same value-added chain in these products. ${ }^{16}$

Rather than displacing Ireland, Hungary has instead displaced other countries in entering the value-added chain of which Ireland's foreign-owned sector comprises one part. ${ }^{17}$

What of Ireland's other foreign-dominated sectors? In Telecommunications, the Czech Republic is Ireland's leading CEE export market, while Ireland again has a trade deficit with Hungary in these products. The bulk of Ireland's exports in this case arise in sub-sectors 764.17 and 764.93 while most of Ireland's imports from Hungary are in sub-sector 763.81, again suggesting that Ireland and Hungary are producing complementary rather than competing products.

In Electrical Machinery, most of Ireland's exports go to Hungary but the country has run trade deficits in the recent past with both the Czech Republic and Poland. Analysis of the disaggregated data again shows that Ireland's exports to CEE countries and imports from these countries tend to be in different sub-sectors. 
These data indicate that fears of direct competition between Ireland and the CEE countries within sub-categories of FDI may be overstated. One cannot be overly sanguine about this however as we know from the analysis of pre-EU accession Irish data that the measures of revealed comparative advantage which underlie this relatively optimistic assessment will not necessarily serve as accurate predictors of the post-enlargement environment if the pattern of FDI flows changes; Barry and Hannan (2002a).

If the more pessimistic scenario in which CEE countries divert FDI flows away from Ireland does come to appear likely, what steps could the Irish authorities take to counter the threat? One part of the required response would focus on cost competitiveness. It is clear that a major factor behind increased wage demands in Ireland in recent years is the price of housing. The government could consider more radical solutions to the problem than were embraced in the various Bacon reports on house prices. ${ }^{18}$ The other elements of the response are in more traditional areas of industrial policy. If the computer sector for example appeared to be in danger of relocating dramatically to some of the new EU member states, the development agencies could seek to narrow Ireland's specialisation into certain niche stages of the production and development process. The other necessity would be to focus more strongly on capturing new sunrise industries as they emerge into the international arena, which is consistent with the strategy advocated in the Forfás document Enterprise 2010.

\section{MIGRATION ISSUES}

Enlargement brings with it the possibility of substantial migration flows from CEE countries to the EU15. Most studies that have been carried out suggest however that the inflow of migrants will in fact be quite modest for countries other than Germany and Austria, and that even in these latter countries the economic effects will not be substantial. Nevertheless, the EU incumbents generally favour only a gradual opening up of labour markets, in the knowledge that ongoing convergence in living standards will make migration a less desirable option. There is indeed a precedent for such a transition period; while Greece acceded to the EU in 1981 and Spain and Portugal in 1986, labour mobility was restricted until 1988 in the former case and until 1992 in the latter.

Although the Irish government had earlier announced that it did not intend to impose a transition period (with the Minister for Foreign Affairs writing in March 2002 that "Ireland took the decision to allow the citizens of new EU member-states full and free access to live and work here from the first day of accession"), that position appeared later to be reversed as the unemployment situation deteriorated. ${ }^{19}$

Estimates of likely migration patterns take into account income differences, distances and traditional ties between sending and receiving economies, the states of the relevant labour markets, the demographic profile of the home-country 
population, and the existence of emigrant networks. On the basis of analysis of previous migration experiences between e.g. Southern and Northern Europe or Eastern and Western Germany, results are then extrapolated, mutatis mutandis, to the post-accession situation prevailing between the CEEC10 and the EU15.

The percentage of the population of the CEEC10 of employable age is generally higher than is the case for Germany, current unemployment rates are rather similar, and income and wage differences are of course large. Studies generally find that the largest emigration rates can be expected from Poland, Romania and Bulgaria, mainly because of their relatively high income disadvantages. Of these, the Poles are generally better prepared for emigration, in terms of educational qualifications and access to emigrant networks.

Consensus estimates suggest that no more than 3 million Central and Eastern Europeans will migrate to Western Europe over the next 15 to 20 years. This would comprise 1 percent of the EU population and 2 to 3 percent of the CEEC population. ${ }^{20}$ Studies indicate a maximum of 335,000 immigrants to the West in the first year, falling to an annual flow of 100,000 in the medium term, based on an assumed convergence of 2 percent per annum between CEE10 and EU income levels and no strong changes in unemployment differentials. Most of these inflows, furthermore, will go to Germany and Austria, which are the end location for over 80 percent of CEE migrants at present.

On the basis of the Irish numbers however, these studies appear to us to underestimate the likely immigration flows. By the early 2000s CEE immigrants already comprised around 0.7 per cent of the Irish population, even though immigration rules were quite restrictive.

There were over 15,500 CEE immigrants on work permits in 2001 and almost 17,000 in 2002. (These numbers should not be added together; both years are shown for comparison purposes only). There had been, in addition, a cumulative 11,500 applications from CEE citizens for refugee status between 1998 and 2002. ${ }^{21}$ 
Table 10: CEE Immigration to Ireland

\begin{tabular}{|l|c|c|c|}
\hline \multirow{2}{*}{} & \multicolumn{2}{|c|}{ Work permits issued } & $\begin{array}{c}\text { Applications for } \\
\text { Asylum 1998-2002 }\end{array}$ \\
\cline { 2 - 3 } & 2001 & 2002 & \\
\hline Bulgaria & 518 & 753 & 410 \\
Czech Rep & 1454 & 1138 & 735 \\
Estonia & 1072 & 820 & 164 \\
Hungary & 557 & 379 & 46 \\
Latvia & 4365 & 3958 & 223 \\
Lithuania & 2909 & 3816 & 638 \\
Poland & 2497 & 3142 & 1400 \\
Romania & 1776 & 2459 & 7763 \\
Slovakia & 465 & 459 & 193 \\
Slovenia & 11 & 13 & 0 \\
\hline Total CEE & 15624 & 16937 & 11572 \\
\hline
\end{tabular}

Sources: Work permit numbers from Department of Enterprise, Trade and Employment (http://www.entemp.ie/lfd/wp-statistics.htm);

Asylum seeker numbers from Department of Justice.

The impact of immigration on host country labour markets and incomes per head will depend primarily on immigrant skill levels relative to the indigenous population. If skill levels are equivalent, then with international capital mobility the effects are minimal. If immigrants are less skilled, the distribution of income becomes less equitable as downward pressure is exerted on the unskilled wage. Unemployment may also rise, as it tends to be concentrated among the less skilled. The net fiscal costs of immigration will also be larger as unskilled immigrants use more government services and pay less tax. All of these effects are reversed of course if immigrants are more highly skilled than the indigenous population, though it must be noted that immigrants frequently work in occupations that do not fully employ their qualifications.

The studies cited above suggest that these effects on EU15 labour markets, whether positive or negative, will all be small, because of the modest increase in population size envisaged. There will also be a modest drop in the EU15 terms of trade because of the expansion of output that immigration will generate. Several studies suggest that German GDP per head would fall by only 0.8 percent even if all CEE immigrants were low skilled. $^{22}$

These studies, understandably, do not focus much attention on Ireland, given that they do not predict substantial flows of workers into this country. Immigrant flows into the Irish labour force over the 1990s are known to have been relatively highly 
skilled, however. Suggested reasons for this include the fact that more highly educated people will have more information about Ireland as a destination, and relatively high income inequality levels may attract a higher ratio of skilled workers. The skill mix in turn has been found to have contributed to the slowdown in earnings inequality growth. ${ }^{23}$ One can only speculate as to whether this same skill mix will continue to prevail upon EU enlargement.

One finding from Germany that may be of interest however, given current cost overruns in implementing the National Development Plan, is that temporary migration possibilities afforded to CEE construction workers were found to have increased competition substantially in the sector through increased subcontracting to CEEC firms; Boeri et al. (2000).

\section{MACROECONOMIC AND BUDGETARY ISSUES}

Some commentators have suggested that the scale and effects of the CEEC10 enlargement can be gauged by reflecting on the experience of German reunification, implying that enlargement might involve substantial deficit spending and rising interest rates. This is most unlikely to happen because the scale of budgetary support offered will be much less than in the case of German reunification.

Most analyses carried out previous to the Copenhagen agreement of December 2002 arrived at an estimated net cost of enlargement to the EU budget of around 20 billion euro per annum. Thus Baldwin, Francois and Portes (1997) assume that Structural Funds expenditures will be capped at 5 percent of CEE GDP, and that average CAP payments to CEE farmers are equivalent per hectare (rather than per person) to those paid to EU farmers (which with low CEE productivity reduces the cost substantially). Summing these costs and subtracting a contribution of 1 percent of candidate countries' GDP generates a figure of less than 20 billion euro for the Visegrad 4 (Czech Republic, Slovakia, Hungary and Poland). ${ }^{24}$

An alternative approach is followed de la Fuente and Doménech (2001). They calculate that the redistributive impact of the total EU budget is equivalent to a subsidy or tax of 5.76 percent of the difference (in purchasing power terms) between an EU citizen's gross income and EU average income. If this degree of redistribution were maintained and extended to new member states the required transfers to CEE countries would sum to 19.5 billion euro or one quarter of one percent of EU15 GDP; CEPR (2002).

The Berlin Summit of 1999 scaled down these figures, and it now appears however that the recent deal struck at Copenhagen is even less generous again.

The main expenditure items in the EU budget are the Common Agricultural Policy, accounting for around half of the budget, and the Structural (and Cohesion) Funds 
which account for a further 30 percent or so. The Commission held to its opening position on both these items in negotiations with the CEEC. CEE farmers are to receive 25 percent of the direct payment per head going to EU farmers in 2004, rising to 30 percent in 2005 and 35 percent in 2006, with a gradual increase to 100 percent by 2013. Structural Funds payments per head will come to 137 euro per capita for CEE countries in 2006, compared to a current average of 231 euro for the existing four Cohesion countries. In addition, in accordance with the "Own Resources" decision of 29 September 2000, the new Member States are to fully contribute to the financing of EU expenditure as of the first day of accession. ${ }^{25}$

These various aspects of the budgetary negotiations raised the possibility that some accession states would become net contributors to the EU budget upon accession (given time delays in drawing down EU funds). The Commission agreed therefore to a new temporary heading $\mathrm{X}$ to include temporary budgetary compensation for the years 2004 to 2006 to avert this possibility, and to include as well a special lump sum cash flow facility which granted Poland 1 billion euro which had been originally designated as structural funds. Unlike in the case of structural funding this amount would be transferred immediately to the Polish budget, it can be spent at will, and will avoid the co-financing requirement associated with structural funds expenditures.

These various figures are presented in tables $11 \mathrm{a}$ and $\mathrm{b} .^{26}$ 
Table 11a: Maximum enlargement-related appropriations for commitments for 10 new Member States (euro millions, 1999 prices)

\begin{tabular}{|c|c|c|c|}
\hline & 2004 & 2005 & 2006 \\
\hline $\begin{array}{l}\text { Heading 1: Agriculture } \\
\text { of which: }\end{array}$ & 1,897 & 3,747 & 4,147 \\
\hline a) Common Agricultural Policy & 327 & 2,032 & 2,322 \\
\hline b) Rural development & 1,570 & 1,715 & 1,825 \\
\hline $\begin{array}{l}\text { Heading 2: Structural actions } \\
\text { of which: }\end{array}$ & 6,095 & 6,940 & 8,812 \\
\hline a) Structural fund & 3,478 & 4,788 & 5,990 \\
\hline b) Cohesion Fund & 2,617 & 2,152 & 2,822 \\
\hline $\begin{array}{l}\text { Heading 3: } \\
\text { Internal Policies and Additional } \\
\text { Transitional Expenditure } \\
\text { of which: }\end{array}$ & 1,421 & 1,376 & 1,351 \\
\hline a) Existing policies & 882 & 917 & 952 \\
\hline b) Trans. nuclear safety measures & 125 & 125 & 125 \\
\hline c) Transitional institution building measures & 200 & 120 & 60 \\
\hline d) Transitional Schengen measures & 286 & 286 & 286 \\
\hline Heading 5: Administration & 503 & 558 & 612 \\
\hline $\begin{array}{l}\text { Total Maximum Appropriations for } \\
\text { Commitments } \\
\text { (Headings } 1,2,3 \text { and } 5 \text { ) }\end{array}$ & 9,952 & 12,657 & 14,958 \\
\hline
\end{tabular}

Table 11b: Heading $X$ for 10 new member states, (euro millions, 1999 prices)

\begin{tabular}{|l|c|c|c|}
\hline & $\mathbf{2 0 0 4}$ & $\mathbf{2 0 0 5}$ & $\mathbf{2 0 0 6}$ \\
\hline Special cash flow facility & 998 & 650 & 550 \\
Temporary budgetary compensation & 262 & 479 & 346 \\
\hline
\end{tabular}


The Copenhagen agreement represents a considerably better deal for incumbent EU members than had long been anticipated. Rather than the 20 billion euro per annum estimate of Baldwin, Francois and Portes (1997) and CEPR (2002), these figures sum to 41 billion euro over three years. With 15 billion to be covered by new member states' contributions the net cost comes to only 26 billion euro, while some speculate that the likely inability of the accession countries to draw down all the funds available to them may reduce the net cost to as little as 10.3 billion euro over the three year period 2004-2006. ${ }^{27}$

We will assess the cost to Ireland under two scenarios: the original estimate of a net cost to incumbents of 20 billion euro per annum, and the new more likely estimate of 9 billion per annum. (The reader can easily scale down our calculations to the much lower estimate of the Enlargement Commissioner if desired).

Based on the current sharing of budgetary costs and benefits across EU member states, Ireland's yearly contribution, if the net cost were 20 billion per annum, would be around 200 million euro. ${ }^{28}$ This falls to 90 million if the lower estimate of the net cost to the EU is accepted. Either of these sums would be deemed manageable.

The cost to Ireland escalates dramatically however if costs and benefits were to be redistributed within the EU in line with current income levels. It is well known that Germany bears a disproportionate share of the current burden while countries like Ireland and France contribute substantially less than the figure warranted by their current income levels. Over time it has to be envisaged that a more equitable sharing of the burden will be negotiated among EU member states. de la Fuente and Doménech (2001) calculate that Ireland is currently oversubsidised to the tune of 2 billion euro per annum. Given that any scaling upwards of the budgetary costs of enlargement will raise the profile of this item on the EU agenda, there may be a very substantial change over time in the flow of funds between Ireland and the rest of the EU.

The implications of these developments for the Irish exchequer will depend on how CAP reform proceeds. The present operation of the CAP entails a subsidy to farmers (and non-EU consumers) by Irish consumers and EU taxpayers. ${ }^{29}$ This element of income redistribution is not done via the Irish exchequer, and its removal as part of CAP reform would not have exchequer implications. Redistributing the burden of agricultural subsidies back onto member-state governments would have major implications however.

The temporal dimension to these issues also needs to be borne in mind. CAP payments are set to rise gradually, while Structural Fund allocations, at a little over 1 percent of CEE GDP, are small in comparison to the allocations made to the Cohesion countries and might also therefore be expected to rise over time. On the other hand, CEE countries are likely to be converging on the EU15 in terms of income per head over this period, which will reduce the need for transfers. 
While the EU has taken great care to ensure that the budgetary and interest rate costs of enlargement are tiny compared to those entailed by German reunification, an EUwide fiscal expansion, were it to arise at some time in the future, would nevertheless exert upward pressure on interest rates, as could moves to hasten the entry of the candidate countries into EMU. We complete this section by looking at the sectoral implications for the Irish economy of such possible macroeconomic developments.

In its report on the economic implications for Ireland of participation in EMU, ESRI (1996) identified certain sectors of the Irish economy that are particularly vulnerable to high interest rates. Such vulnerability was argued depends both on product characteristics and on industrial structure. Durable goods, occasional purchases, house-building materials and construction are all likely to be quite sensitive for example, while firms in low-margin sectors or with high levels of indebtedness will also be particularly vulnerable. Within manufacturing, the most sensitive sectors according to the ESRI analysis included Non-Metallic Minerals; Textiles, Clothing and Footwear; Wood and Furniture; Paper and Printing; Rubber and Plastics, and some segments of Food, Drink and Tobacco.

It is noteworthy that these are all low-technology sectors and all have declined as a share of manufacturing (and total) employment since the ESRI study was carried out. This suggests that Irish manufacturing employment is now less vulnerable to high interest rates, even if these should arise in the future as a consequence of enlargement, than was the case even a decade ago.

\section{CONCLUSIONS}

Enlargement will have important economic implications for Ireland. Trade expansion for example seems certain. Baldwin, Francois and Portes (1997) estimate that Ireland will receive 0.3 percent of the total gains from trade accruing to the EU15. ${ }^{30}$ Most Irish export sectors will gain. The Western European sectors threatened by enlargement are generally agreed to include Food Processing and Textiles, Clothing and Footwear. Our analysis suggests that the Irish food processing sector is in fact likely to gain, as it produces a very different range of products to those into which the CEE countries are likely to specialise. We expect that Irish companies in this and a number of other sectors will, on the basis of proprietary assets in management and sectoral experience, engage in outward FDI into Central and Eastern Europe. The development of trade with the CEEC will also offer outsourcing possibilities, particularly in labour-intensive sectors such as Textiles and Clothing. Most conventional trade analyses do not take these possibilities into account in assessing gains from further market integration.

While Ireland's foreign-owned sector stands to gain substantially from the opening up of export opportunities in Central and Eastern Europe, there is also the possibility that enlargement will divert inward FDI away from Ireland. There is no sign that 
anything of this nature has happened as yet however. In fact our analysis shows that Ireland and Hungary currently trade complementary Office and Data Processing products, and that Hungarian exports to Ireland represent one link in a value chain that generates strong Irish exports to the rest of the world. Further fragmentation of the value-added chain may be as likely an outcome as the diversion of FDI flows away from Ireland.

Enlargement will also open up the possibility of labour migration. Most studies estimate that inflows will be quite modest, summing to perhaps 1 percent of the EU15 population by the year 2030 . The vast majority of these migrants will go to Germany and Austria. The impact on wages and living standards will depend on the skills of the migrants, but if inflows are as modest as studies suggest, these effects will be fairly negligible.

Finally, we looked at the macroeconomic and budgetary implications of enlargement. The annual cost to the Irish Exchequer in the early years is likely to lie closer to the 90 than the 200 million euro figures discussed in the text. A root and branch review of the distribution of the EU budget could cost the country up to 2 billion euro per annum, reflecting the extent to which the country is oversubsidised at present relative to its income level.

Even if the narrowly defined economic benefits for EU incumbents turn out to be quite modest it is important to remember, as Baldwin, Francois and Portes (1997) point out, that the outcome of the narrow economic calculus employed here pales into insignificance when evaluated against the larger implications of enlargement. Eastwards expansion of the EU is primarily about the security and stability of the continent and the reconstruction of Europe's post-Cold War political architecture. 


\section{Endnotes}

1. This suggestion of a possible doubling of trade with CEE countries is very close to the figure predicted by Brulhart and Kelly (1999). They estimate a gravity model that takes account of trade barriers represented by distance and non-EU membership and use it to predict the effects of enlargement on trade. Predicted effects are much larger if partial income convergence of the CEECs on the EU is also allowed for. They caution however that any expansion is from a relatively low base. At present Ireland-CEE trade (the sum of exports and imports) comes to a little over 1 percent of Irish GDP.

2. It also tends to run a very much smaller deficit with Latvia, largely driven by imports of Wood and Petroleum Products.

3. Some more disaggregated studies predict that the CEECs will gain in sectors that are abundant in land and unskilled labour while affording opportunities for the skill-intensive segments of the EU food processing sector; Stolwijk (2000).

4. The material in this paragraph is based on Lejour et al (2001) and Baldwin et al. (1997).

5. "Carmakers up sticks for eastern Europe"; Financial Times, October 10, 2002.

6. These data depict averages over the years 1995-97, the latest years for which the Daisie database gives data for the entire EU.

7. Revealed comparative advantage is conventionally measured by applying this formula to export rather than employment data. We use employment data to surmount the transfer pricing problems that arise in the Irish case, and also to allow us distinguish later between Ireland's indigenous and foreign sectors.

8. Tables C.4.1 of the OECD (2001) publication Science, Technology and Industry Scoreboard, shows that foreign affiliates comprise 48 percent of Irish manufacturing employment. France is next highest at 28 percent, while the equivalent figures for the UK and Germany are 18 percent and 6 percent respectively.

9. For Ireland, Matthews (2000) shows that, for 1999, cattle accounted for 33 per cent of gross agricultural output, milk for 35 per cent, and crops, pigs, sheep and other for 14 per cent, 6 per cent , 5 per cent and 8 per cent respectively.

10. This more detailed account of Irish food processing contradicts the simulated prediction of Lejour et al. (2001, page 23) that "food processing declines in all EU countries".

11. For more on this see Barry, Gorg and McDowell (2002).

12. Proximity is also generally found to be an important factor behind outsourcing however, suggesting that Ireland's links with the CEEC along this dimension are unlikely to reach Austrian levels.

13. Transport infrastructure plays an important role in calculations of a country's centrality or "closeness to purchasing power". Schürmann and Talaat (2000) provide a recent ranking of EU and CEE countries in this regard. Their index is based on a measure of travel costs between points within the overall region weighted by the purchasing power that each point represents. The most peripheral regions at present, they find, are the Baltic states, Northern Sweden and Finland, and Bulgaria and Romania. Hungary, Slovenia, the Czech and Slovak Republics and the southwest corner of Poland are no more peripheral than Ireland, Spain or Portugal, and less peripheral than Greece. Interestingly, these authors also present a projection for the year 2016 based on the assumption of EU accession (with its associated reduction in border delays) and the implementation of current transport infrastructure plans for Central and Eastern Europe and EU incumbents. In this scenario, some regions in Poland, the Czech Republic, Slovakia, Hungary, Eastern Germany and Portugal move ahead of Ireland, with Greece left even further behind. 
14. The macroeconomic environment will of course be heavily constrained by adherence to the Maastricht criteria. Fodors et al. (2002) rank the CEE and EU periphery countries in terms of institutional and administrative environments and find that countries such as Estonia and the Czech Republic score close to Ireland in these respects.

15. We include data on Estonia as well as on Ireland's main trading partners in the region given the emerging strength of its telecommunications sector, based largely on overseas production by Finnish firm Nokia.

16. In terms of Irish-Hungarian intra-industry trade in section 759.97, the unit values (per tonne) have been consistently higher for Irish exports, indicating the simultaneous import of lower-quality and export of higher quality products within Ireland's main export subsector.

17. As to which countries were displaced: in 1989/90 43 percent of imports to Ireland of SITC 752.60 and SITC 752.70 products came from Western Europe, 32 percent from the US and 25 percent from Asia. In 2000/01 by contrast, 39 percent came from Western Europe, only 8 percent from the US, 50 percent from Asia and 3 percent from Hungary. This sub-sector of industry was therefore migrating from west to east.

18. One such is to increase densities considerably by easing height restrictions in new housing developments, and to build up state-owned land banks purchased at non-rezoned agricultural-use prices; see e.g. Drudy (2001).

19 "State reserves right to require job permits"; Irish Times, September 26, 2002.

20. Boeri et al. (2000); Fertig and Schmidt (2000); Bauer and Zimmermann (1999); Lejour et al. (2001).

21. By contrast Boeri et al (2000; part A, page 127), the most widely cited study on the immigration implications of enlargement, predict the stock of CEE resident in Ireland to rise from a figure of 200 that they quote for 1998 to a total of 900 by 2030 !

22. Bauer and Zimmermann (1999); Lejour et al. (2001).

23. Barrett et al. (2002).

24. It is important to note however that regardless of agreements reached in the near future over reform of the CAP and Structural Funds programmes, further renegotiations will occur in the wake of EU enlargement. Baldwin, Francois and Portes (1997) offer some speculations as to the voting coalitions likely to emerge at this time.

25. The postponement of accession to May however allows them receive their full expenditure allocations for 2004 while paying only $2 / 3$ of their budget contributions for that year.

26. Source: Copenhagen European Council 12-13 December 2002 Presidency conclusions; European Commission Press Room Doc/02/15 (Annex 1), available at: http://europa.eu.int/rapid/start/cgi/guesten.ksh?p_action.gettxt=gt\&doc=DOC/02/15|0|RA PID\&lg=EN\&display $=$

27. This is the assessment of the European Enlargement Commissioner who proclaimed exultantly to the parliament Foreign Affairs Committee on January 23 that "We're getting enlargement cheaper than we thought we would". He confirmed that the final deal on expenditures agreed at Copenhagen was 1.7 billion euro less than the maximum ceiling fixed by Berlin for commitments in 2004-2006, and 9.4 billion euro less than the maximum available payments. [http://europa.eu.int/comm/enlargement/docs/newsletter/latest_weekly.htm].

28. Baldwin, Francois and Portes (1997) and CEPR (2002) concur in this estimate.

29. See Matthews (2001).

30. They estimate the EU15 gain at a modest 11.2 billion ecu (at 1992 prices). 


\section{References}

Anderton, B. and P. Brenton, 1999. "Outsourcing and Low-Skilled Workers in the UK”, Bulletin of Economic Research, Vol. 51 (4), pp. 267-285.

Baldwin, R.E., J.F. Francois and R. Portes, 1997. "The Costs and Benefits of Eastern Enlargement: the Impact on the EU and Central Europe", Economic Policy, Vol. 24, pp. 125-176.

Barrett, A., J. FitzGerald and B. Nolan, 2002. "Earnings Inequality, Returns to Education and Immigration into Ireland”, Labour Economics, Vol. 9, pp. 665-680.

Barry, F., 2002. "EU Accession and Prospective FDI Flows to CEE Countries" in R. Lipsey (ed.), Foreign Direct Investment in the Real and Financial Sector of Industrial Countries, Frankfurt: Deutsche Bundesbank, forthcoming.

Barry, F., H. Gorg and A. McDowell, 2002. "Outward FDI and the Investment Development Path of a Late-Industrialising Economy: Evidence from Ireland", Regional Studies, forthcoming.

Barry, F. and A. Hannan, 2001. "Will Enlargement Threaten Ireland's FDI Inflows?”, Quarterly Economic Commentary; Dublin: ESRI.

Barry, F. and A. Hannan, 2002a. "FDI and the Predictive Powers of Revealed Comparative Advantage Indicators", unpublished ms, University College Dublin.

Barry, F. and A. Hannan, 2002b. "Product Characteristics and the Growth of FDI", unpublished ms, University College Dublin.

Bauer, T. and K. Zimmermann, 1999. "Assessment of Possible Migration Pressure and its Labour Market Impact Following EU Enlargement to Central and Eastern Europe", IZA Research Report No. 3, Bonn.

Boeri, T., H. Brücker et al., 2000. "The Impact of Eastern Enlargement on Employment and Labour Markets in the EU Member States", Final Report to European Commission, available at: http://europa.eu.int/comm/employment_social/empl\&esf/enlargement_en.htm (A summary is also available as "Eastern Enlargement and EU labour markets: Perceptions, Challenges and Opportunities", forthcoming in World Economy).

Brulhart, M., and M. Kelly, 1999. "Ireland's Trading Potential with Central and Eastern European Countries: A Gravity Study", Economic and Social Review, Vol. 30 (2), pp. 159-174.

CEPR, 2002. "Who's Afraid of the Big Enlargement?", Policy Paper No. 7, Centre for Economic Policy Research, London. 
de la Fuente, A. and R. Domenech, 2001. "The Redistributive Effects of the EU Budget: An Analysis and Proposal for Reform”, Journal of Common Market Studies, Vol. 39 (2), pp. 307-30.

Drudy, P.J., 2001. "Towards Affordable Housing: the Case for a New Approach" in P.J. Drudy and A. MacLaran (eds.), Dublin: Economic and Social Trends, Centre for Urban and Regional Studies, Trinity College Dublin.

Dunning, J., 1997a. "The European Internal Market Programme and Inbound Foreign Direct Investment, Part One", Journal of Common Market Studies, Vol. $35(1)$, pp. 1-30.

Dunning, J., 1997b. "The European Internal Market Programme and Inbound Foreign Direct Investment, Part Two", Journal of Common Market Studies, Vol. 35 (2), pp. 189-223.

Egger, P., M. Pfaffermayr and Y. Wolfmayr-Schnitzer, 2001. "The International Fragmentation of Austrian Manufacturing: the Effects of Outsourcing on Productivity and Wages", The North American Journal of Economics and Finance, Vol. 12, pp. 257-27.

ESRI, 1996. "Economic Implications for Ireland of EMU”, Policy Research Paper, No. 28; Dublin: The Economic and Social Research Institute.

Fertig, M. and C. Schmidt, 2000. "Aggregate-level Migration Studies as a Tool for Forecasting Future Migration Streams", IZA Discussion Paper, No. 183, Bonn: Institute for the Study of Labour (IZA).

Ferto, I. and L. J. Hubbard, 2001. "Intra-Industry Trade in Agri-Food Products between Hungary and the EU", available at:

http://www.mek.iif.hu/porta/szint/tarsad/kozgazd/elmelet/nyarimuh/html/ferto.pdf

Fodors, F., D. Piazolo and R. Schweickert, 2002. "Ready to Join the EU? On the Status of Reform in the Candidate Countries", World Economics, Vol. 3(4), pp. 4372 .

Forfás, 2001. Statement on Outward Direct Investment, Dublin: Forfás.

Forfás, 2000. Enterprise 2010, Dublin: Forfás.

Francois, J. and M. Rombout, 2001. "Trade Effects from the Integration of the Central and East European Countries into the European Union", SEI Working Paper, No. 41, Sussex: Sussex European Institute. 
Henrichsmeyer, W., J. Köckler, T. Möllmann and A. Quiring, 2000. "Development of a Policy Information System for Agricultural Sectors in Transition Countries", in S. Tangermann and M. Banse (eds.), Central and Eastern European Agriculture in an Expanding European Union, Manchester: CABI. http://www.cabi-publishing.org/Bookshop/Readingroom/0851994253.asp

Lejour, A., R. de Mooij and R. Nahuis, 2001. "EU Enlargement: Economic Implications for Countries and Industries", $C P B$ Working Paper, No. 585, The Hague: CPB Netherlands Bureau for Economic Policy Analysis.

http://www.ifo.de/pls/ifo_app/CESifoSwitch?setPage=ifoinstitute.htm

Matthews, A., 2000. "Agriculture, Food Safety and Rural Development" in J. O'Hagan (ed.), The Economy of Ireland, eighth edition, Dublin: Gill and Macmillan.

Matthews, A., 2001. "How Important is Agriculture and the Agri-Food Sector in Ireland?", Irish Banking Review, Winter, pp. 28-40.

Midelfart-Knarvik, K-H., H. Overman, S. Redding and A. Venables, 2000. "The Location of European Industry", Economic Papers, No. 142, European Commission: Directorate General for Economic and Financial Affairs.

Pavelin, S., 2000. "The Geographical Diversification of Leading Firms in the EU", Centre for Economic Research Working Paper, No. 15, Dublin: University College Dublin.

Schürmann, C. and A. Talaat, 2000. "Towards a European Peripherality Index", Report for European Commission DGXVI Regional Policy, available at: http://irpud.raumplanung.uni-dortmund.de/irpud/pro/peri/ber53_gesamt.pdf

Stolwijk, H., 2000. "The Dutch Food and Agricultural Sectors and the Enlargement of the EU", Netherlands Central Planning Bureau Report 2000/1, The Hague: CPB Netherlands Bureau for Economic Policy Analysis.

UNCTAD, 2000. World Investment Report, Geneva: United Nations Conference for Trade and Development. 